\title{
Transbronchial Needle Aspiration and Mediastinal Staging in Lung Cancer
}

\author{
M. Solèr \\ Pneumologie, St. Claraspital, Basel, Schweiz
}

For many years to come, surgery will remain the only curative treatment for non-small-cell lung cancer in early disease stages, and for as many years, the preoperative staging of mediastinal lymph nodes will remain central to the decision whether a patient should undergo surgery or not.

The staging methods have changed considerably with the advent of whole-body FDG-PET scan [1], which can now be combined with chest CT scans [2]. The imaging techniques for the mediastinum, however, are still limited in their sensitivity and specificity. The CT size criteria for mediastinal nodes have long been questioned [3], because inflammatory lymph node enlargements should not exclude patients from the opportunity of curative resection. Metabolic information from FDG-PET, on the other hand, can also show positive signals in inflammatory lymph nodes.

Even with this combined information, however, falsepositive and false-negative results occur. In the light of the importance of correct mediastinal staging in non-smallcell lung cancer, where missing a possible resection means missing a chance to cure the patient, we still need cytologic or histologic confirmation of decisive mediastinal node involvement. Clearly, the method of choice, the gold standard, is mediastinoscopy, which allows for the histologic assessment of the most important mediastinal node locations. Although a relatively safe surgical procedure, mediastinoscopy is still an intervention requiring general anaesthesia and an experienced chest surgeon. So, the goal is to avoid unnecessary mediastinoscopies where possible.

Today, no resection of lung cancer should be performed without previous flexible bronchoscopy. This is usually the method of choice for the preoperative histologic assessment of the primary tumour. During the same session, transbronchial needle aspiration (TBNA) techniques allow assessment of the involvement of the most important mediastinal lymph node locations in the paratracheal and tracheobronchial as well as infracarinal locations. If interpreted with caution (lymphocytes need to be in the specimen in order to exclude contamination of the sample with bronchial secretions, which may potentially contain tumour cells), false-positive cytologic results are extremely rare [4]. In experienced hands, this technique is safe and requires little time (a few minutes per location). The negative predictive value has only rarely been assessed, but may be as high as $80 \%$ (personal experience). Even with a sensitivity of only $65 \%$ (in the study by Hermens et al., this issue of Respiration [5]), there is still a relevant number of mediastinoscopies that can be omitted in TBNA-diagnosed N3 disease. In addition, TBNA adds to the overall diagnostic yield of flexible bronchosco-

\begin{tabular}{ll}
\hline KARGER & (c) 2003 S. Karger AG, Basel \\
Fax +4161306 1234 & 0025-7931/03/0706-0572\$19.50/0 \\
$\begin{array}{l}\text { E-Mail karger@karger.ch } \\
\text { www.karger.com }\end{array}$ & $\begin{array}{l}\text { Accessible online at: } \\
\text { www.karger.com/res }\end{array}$
\end{tabular}

\author{
Prof. M. Solèr \\ Pneumologie, St. Claraspital \\ CH-4016 Basel (Switzerland) \\ Tel. +416168584 73, Fax +41616858469 \\ E-Mail markus.soler@claraspital.ch
}


py. If the histology needle is used, which may be a little harder to push through the bronchial wall, this relates not only to the diagnosis of cancers, but also to benign diseases, such as sarcoidosis, tuberculosis or lymphomas.

Contralateral lymph node involvement proven by TBNA still means inoperability if TBNA was performed with a staging concept in mind, beginning with the node most distant from the primary tumour. Infracarinal or ipsilateral involvement is more difficult to weigh up in the clinical context. If the patient is to undergo neoadjuvant chemotherapy for N2 disease, based on a positive cytology only, it will never become clear if there had been microscopic involvement of the contralateral $\mathrm{N} 3$ nodes, which would still exclude a patient from this therapeutic strate- gy. I would, therefore, strongly advocate performing a mediastinoscopy before neoadjuvant chemotherapy in N2 disease, even if the available staging information includes an FDG-PET compatible with TBNA cytology and CT scan. With the development of new neoadjuvant chemo- and radiotherapy concepts, requiring precise mediastinal staging information, the role of TBNA in mediastinal staging will have to be reevaluated in the context of PET and CT information in prospective clinical trials. Only this approach will allow us to perform relevant costbenefit analyses for the TBNA technique. The positive proof of N3 involvement by TBNA cytology or histology, however, will remain of decisive value.

\section{References}

TBNA and Mediastinal Staging in Lung Cancer
1 Van Tinteren H, Hoekstra OS, Smit EF, van den Bergh JH, Schreurs AJ, Stallaert RA, van Velthoven PC, Comans EF, Diepenhorst FW, Verboom P, van Mourik JC, Postmus PE, Boers M, Teule GJ: Effectiveness of positron emission tomography in the preoperative assessment of patients with suspected non-smallcell lung cancer: The PLUS multicentre randomised trial. Lancet 2002;359:1388-1392.

2 Lardinois D, Weder W, Hany TF, Kamel EM, Korom S, Seifert B, von Schulthess GK, Steinert HC: Staging of non-small-cell lung cancer with integrated positron-emission tomography and computed tomography. N Engl J Med 2003;348:2500-2507.
3 Pretreatment evaluation of non-small-cell lung cancer. The American Thoracic Society and The European Respiratory Society. Am J Respir Crit Care Med 1997;156:320-332.

4 Harkin TJ, Wang KP: Bronchoscopic needle aspiration of mediastinal and hilar lymph nodes. J Bronchol 1997;4:238-249.

5 Hermens FHW, Van Engelenburg TCA, Visser FJ, Thunnissen FBJM, Termeer R, Janssen JP: Diagnostic yield of transbronchial histology needle aspiration in patients with mediastinal lymph node enlargement. Respiration 2003;70: 631-635. 